\title{
PREVALENCE OF DENTAL DECAY AND PERIODONTAL DISEASES AMONG CHILDREN SUFFERING FROM CONGENITAL HEART DISEASES. A LITERATURE REVIEW - PART II
}

\author{
Teodora Nikolova ${ }^{1}$, Radosveta Andreeva ${ }^{1}$, Milena Georgieva ${ }^{1}$, Petar Shivachev ${ }^{2}$ \\ ${ }^{1}$ Department of Pediatric Dental Medicine, Faculty of Dental Medicine, \\ Medical University of Varna \\ ${ }^{2}$ Department of Pediatric Medicine, Faculty of Medicine, Medical University of Varna
}

\begin{abstract}
Dental decay is one of the most prevalent chronic and infectious diseases for mankind. It is defined as "a dynamic process, taking place in the tooth bacterial biofilm (plaque), which results in a disturbance of equilibrium between tooth substance and the surrounding plaque fluid and finally results in a loss of minerals from the tooth surface - demineralisation." Fluoride plays an important role in dental decay prevention and stimulates self-healing of minor cavities by reducing the demineralisation process and promoting the remineralisation process. Remineralisation occurs frequently, especially when the biofilm $\mathrm{pH}$ is restored by saliva, which acts as a buffer. The adequate salivary production is of great importance for maintaining a normal physiology in the oral cavity.

It is known that children with congenital heart disease (CHD) frequently require regular long-term medication, but the knowledge of oral health effects caused by long-term medication in medically compromised children is sparse. Many medications used on a long-term basis may contain sugar, have a low $\mathrm{pH}$ or high acidity. There is a strong correlation between xerostomia and pharmacological treatment and a number of drugs have been listed as xerogenic. These drugs include ones with a directly damaging to salivary glands function, such as cytotoxic drugs, medications with anticholinergic activity, drugs which deplete fluid as diuretics, and drugs acting on the sympathetic system, like antihypertensive drugs. Only a few clinical studies have been carried out on the outcome of salivary function with antihypertensive drugs, and the outcome is not clear-cut.

A number of studies have been carried out on the caries prevalence in children with CHD but only five of them were controlled. Child ren with CHD had higher mean values of $\mathrm{dmft} / \mathrm{DMFT}$ indices than healthy children and only a few of them had experienced fillings, indicating an unmet need for operative treatment.
\end{abstract}

Keywords: congenital heart disease (CHD), dental decay, periodontal disease, children, risk factors, medication

Address for correspondence:

Teodora Nikolova

Faculty of Dental Medicine

84, Tsar Osvoboditel Blvd.

9000 Varna

e-mail: tedinikolova1@gmail.com

Received: December 3, 2017

Accepted: December 29, 2017
Saliva as a Risk Factor for Dental Decay and/ or Periodontal Diseases Formation

The adequate saliva formation is of great importance for the normal physiology of oral cavity. Saliva is being produced by the three major pairs of salivary glands - parotid, submandibular and sublingual, and by many more minor ones - labial, buccal, lingual and palatal glands, in an overall volume 
Teodora Nikolova, Radosveta Andreeva, Milena Georgieva et al.

of 0.5-1.0 L per day. Normally, salivary glands should be fully developed around 15 years of age, salivary flow should increase with age and girls should have lower levels of saliva secretion than boys the same age (1-4). Saliva, produced by different salivary glands, has a typical and different composition, which varies within a 24-hour period (1-5). The composition of saliva may change under the influence of different stimuli, as well $(1,6)$. Saliva contains inorganic ions, such as calcium and phosphates, and organic compounds like proteins, carbohydrates, immunoglobulins, and enzymes. In the oral cavity, the product of salivary glands is being mixed with the secretion from the nasal cavity and pharyngeal space, epithelium cells and millions of microorganisms, and the overall product is referred in specialised literature as whole saliva $(1,5)$.

Saliva plays an important role in the complex oral ecosystem. Many crucial for the health of the oral cavity factors may be found among its compounds $(1,7)$. One of the most important functions of saliva is to neutralise the acids, produced in dental plaque. This means that reduced salivary flow automatically puts the patient in higher risk for dental decay and/or periodontal disease formation. Saliva has a lubricating effect over all oral tissues and thus facilitates the processes of mastication, swallowing and speech. Saliva takes part in the initial stages of food digestion, too $(1,5,8)$. Through its buffering capacity, saliva protects the oral cavity from damaging variations of $\mathrm{pH}$ values. By means of some of its antimicrobial agents, such as immunoglobulins, saliva stands as a barrier against bacteria and viruses, preventing their entrance through the oral mucosa. Its composition includes IgG, IgM and IgA, but mainly secretory IgA (sIgA) (1,9). sIgA is mainly produced by plasmatic cells, located in connective tissue, and is being transferred to the excretory canals of major and minor salivary glands $(1,3,10)$. sIgA against Streptococcus mutans (SM) may be found in saliva samples from the majority of children over 3 years of age and the quantity of these antibodies increases proportionately with the time of exposition $(9,11)$.

Salivary glands show dual innervation from both sympathetic and parasympathetic nervous systems. Stimulating the parasympathetic system increases salivary flow, while sympathetic stimulation causes the production of scarce but more viscous sali- va $(1,5)$. Pharmacotherapy is the most common reason for damaged salivary secretion $(3,5,8)$.

\section{Dental Decay}

Dental decay is the most prevalent chronic behavioural infectious disease for mankind. The risk for dental decay occurrence is present during a lifetime. Dental caries is the main reason for pain in the oral cavity region and for the loss of teeth from both primary and permanent dentition (12).

Dental decay is known to be a dynamic disease, which takes place on a specific surface, due to damaged physiological balance between minerals in hard dental tissues on one side, and the liquid phase of plaque, on the other, resulting in de- or remineralisation processes $(5,12,13)$. Demineralisation, due to dental decay, is a process of plaque-induced degradation of minerals (calcium and phosphates) from the hard dental tissues. Remineralisation is defined as net weight gain of mineral ions in hard dental tissues. The new mineral ions take the place of the ions, lost during the previous demineralisation (12-14).

The carious lesion may be reversed if registered and stopped in early stages of formation, but if left untreated, it may destroy the whole crown of the tooth (15). A great number of clinical studies show close correlation between dental decay, being present in primary dentition, and its further presence in permanent dentition (16-19). One of the main aims in pediatric dentistry consists of the struggle to prevent dental decay formation in primary dentition (1).

\section{Pathogenesis of Dental Decay}

The carious lesion forms under the influence of interacting acidogenic bacteria, such as SM and Lactobacilli (LBC), sugar from food, which bacteria metabolise, and a few variable intrinsic and extrinsic factors $(1,15,20)$. The most cariogenic bacterial group in the oral cavity is presented by SM $(1,21)$. Increasing in the overall portion of acidogenic bacteria, such as SM and LBC, in the composition of dental plaque is connected with the formation of dental decay lesions (22). Changes in the composition of plaque, which promote acidogenic species, take place due to changes in the surrounding environmental conditions. Examples for such changes may be reduced salivary secretion, regular sufficient intake of sugar, poor oral hygiene or different combinations of the listed factors (23-26). The low $\mathrm{pH}$ values, gener- 
Prevalence of Dental Decay and Periodontal Diseases Among Children Suffering from Congenital Heart Diseases. ...

ated by the produced acids, change the dynamic homeostasis in microbial ecosystem, causing the future natural selection of more acidogenic and acid-tolerant microbial species. The acids, produced by acidogenic bacteria, will cause demineralisation and lowering of $\mathrm{pH}$ levels below the critical one (5.5), under which no remineralisation processes can take place (27). If demineralisation processes continue, the surface of the tooth will soon show signs of cavitation. On the other hand, if minerals in the saliva, such as fluoride, calcium or phosphate, diffuse into the tooth structure under specific conditions, remineralisation may take place. The remineralised region of the tooth structure is usually more acid-resistant than the restored one. Remineralisation normally takes place all the time if the saliva function is unaffected and thus its buffering systems can properly regulate the acidity in dental plaque (27).

Epidemiology of Dental Decay among Children with Congenital Heart Disease (CHD)

A number of studies show results, concerning the prevalence of dental decay among Swedish children. Two of them, carried out in 2006 and 2007, show that $6-7 \%$ of children at the age of 2 are affected by dental caries $(28,29)$. There is a registered decrease in dental decay prevalence among Swedish children $(30,31)$, but dental decay still stays a frequently encountered diagnosis in primary dentition (32).

Many chronic diseases in childhood are correlated to poor oral health (33). Out of a great number of studies, concerning dental decay prevalence among children with CHD (34-40), only five were

Table 1. Published study results on dental decay prevalence among children with CHD

\begin{tabular}{|c|c|c|c|c|}
\hline Author, Year & Country & Number of patients & Age & Decay/Age group \\
\hline Berger, 1978 (35) & Australia & $\begin{array}{l}\mathrm{CHD}=57 \\
\mathrm{Ctr}=57\end{array}$ & $8-10$ & $\begin{array}{l}\text { Cyanotic CHD had higher Dt, DT } \\
\text { and MT. }\end{array}$ \\
\hline Tasioula et al., 2008(39) & UK & $\begin{array}{l}\mathrm{CHD}=76 \\
\mathrm{Ctr}=47\end{array}$ & $2-15$ & 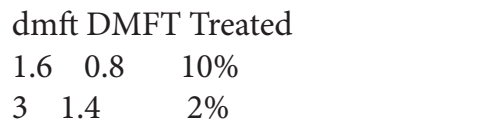 \\
\hline Rai et al., 2009 (38) & India & $\mathrm{CHD}=170$ & $1-16$ & $42 \%$ affected by tooth decay. \\
\hline $\begin{array}{l}\text { Balmer \& BuLock, } 2003 \\
\text { (34) }\end{array}$ & UK & $\begin{array}{l}\text { Children in higher risk } \\
\text { from } \mathrm{IE}=38\end{array}$ & $2-16$ & $39 \%$ with untreated decay lesions. \\
\hline $\begin{array}{l}\text { Pollard \& Curzon, } 1992 \\
\text { (4) }\end{array}$ & UK & $\begin{array}{l}\mathrm{CHD}=100 \\
\mathrm{Ctr}=100\end{array}$ & $2-16$ & $\begin{array}{l}2-4 \mathrm{dmft}=1,8 / 1.6 \mathrm{Ctr} \\
5-9 \mathrm{DMFT}=4.3 / 2.8 \mathrm{Ctr} \\
10-16 \mathrm{DMFT}=10.6 / 0.5 \mathrm{Ctr}\end{array}$ \\
\hline Franco et al., 1996 (36) & UK & $\begin{array}{l}\mathrm{CHD}=60 \\
\mathrm{Ctr}=60\end{array}$ & $2-16$ & $\begin{array}{l}\text { dmft } \quad \text { DMFT } \\
3.7 \quad 2.7-3.4 \\
3.2 \quad 2-2.9 \\
\\
\text { Untreated decay: } \\
\text { CHD }=52 \% \\
\text { Ctr }=32 \%\end{array}$ \\
\hline Da Silva et al., 2002 (6) & Brazil & $\begin{array}{l}\text { Children in higher risk } \\
\text { from } \mathrm{IE}=38 \mathrm{IE}=104\end{array}$ & $2-17$ & $\begin{array}{l}\mathrm{dmft} 2.6 \pm 3.0 \\
\text { DMFT } 4.0 \pm 4.1\end{array}$ \\
\hline Hallett et al., 1992 (37) & Australia & $\begin{array}{l}\mathrm{CHD}=39 \\
\mathrm{Ctr}=33\end{array}$ & $\begin{array}{l}2-15 \\
1-15\end{array}$ & $\begin{array}{ll}\mathrm{dmft} & \mathrm{DMFT} \\
4.2 & 0.9 \\
2.3 & 0.6\end{array}$ \\
\hline $\begin{array}{l}\text { Hayes \& Fasules, } 2001 \\
\text { (43) }\end{array}$ & USA & $\begin{array}{l}\text { Children, planned for } \\
\text { cardiac surgery }=209\end{array}$ & $\begin{array}{l}>6 \\
\text { months }\end{array}$ & $29 \%$ were affected by dental decay. \\
\hline $\begin{array}{l}\text { Urquhart \& Blinkhorn, } \\
1990(40)\end{array}$ & UK & $\mathrm{CHD}=134$ & $4-12$ & $\begin{array}{l}4-6 \mathrm{dmft}=3.3 \\
7-9 \mathrm{DMFT}=3.5 \\
10-12 \mathrm{DMFT}=5\end{array}$ \\
\hline
\end{tabular}


Teodora Nikolova, Radosveta Andreeva, Milena Georgieva et al.

actually controlled studies $(35,36,37,38,39)$. The published results, concerning caries prevalence among children with CHD, are listed in Table 1. In these clinical trials, published between 1978 and 2008, the gravity of CHD and the way of managing results differ, but they all register a greater number of untreated decays, greater treatment needs and higher dental decay prevalence among the CHD patients, compared to healthy children.

The prevalence of dental decay among children is thoroughly examined and it is proven that children with migrant origin (32) and medically compromised children $(17,41,42,43)$, show higher dmft/ DMFT indices, compared to healthy children. There is still not enough information, concerning dental decay prevalence among the continuously enlarging group of children with CHD.

\section{Oral Effects of Pharmacotherapy}

It is known that children with CHD frequently require regular long-term medication (44), but the knowledge of oral health effects, caused by long-term medication in medically compromised children, is sparse (45). Many of the pharmaceutical preparations, prescribed for long-term treatment, have high acidity and contain sugar $(46,47)$. The strong correlation between xerostomy and pharmacological treatment is a fact (48), and many medications are listed as xerogenic (49). These pharmaceutic preparations include such with direct damaging effect on salivary glands as cytotoxic drugs, medications with anticholinergic effect, diuretics and antihypertensive preparations, which affect the sympathetic nervous system (50). Only a few clinical trials had registered if there is a damaged salivary secretion in patients on long-term antihypertensive medication, but the results were not clear cut (51). The effect of P-adrenoreceptor antagonists atenolol and propranolol on salivary flow and composition was examined in healthy men and the results registered no decrease of salivary flow, but lower values of overall saliva protein (52). Patients with hypertonia increase their salivary flow during withdrawal of the P1-selective medication metoprolol (53). Treatment with ACE-inhibitor captopril increases the speed of secretion of non-stimulated and stimulated by chewing of paraffin whole saliva. It also increases the salivary flow from the parotid gland. No deviations from normal saliva com- position were observed (54). Thiazide diuretics are proven to diminish salivary secretion in 34 healthy adult volunteers (55).

For the purpose of maintaining chemical stability, tonicity and physiological compatibility of medications, acids are being used as buffering compounds (45). Fermentable carbohydrates, such as sucrose, may be added to pediatric preparations for making them taste better and thus facilitate the intake. Sugar, added to the composition of the pharmaceutical preparations, causes diminishing of the $\mathrm{pH}$ values in plaque, due to their quick metabolisation to acids by the microorganisms (33). On the other hand, acids in the composition prevent the $\mathrm{pH}$ levels from getting back to normal for a long time after sugar intake. Thus, apart from its effect on salivary secretion, pharmaceutical therapy may have direct damaging effect on oral health by mediating decay and/ or erosion formation $(47,49,56,57)$. Dental erosion is multifactorial disease, defined as "aseptic" or noncarious dissolution of the mineral phase of the tooth from acids, when the surrounding liquid phase lacks these minerals (58). The mineral phase of hard dental tissues is represented mainly by calcium and phosphates, organised most commonly in hydroxyapatite crystals, with critical value of $\mathrm{pH}$ around 5.5 (58). Every matter with lower $\mathrm{pH}$ is capable of causing dissolving of hard dental tissue, leading to either dental decay or dental erosion (59). The etiology behind dental erosion is usually classified as having extrinsic or intrinsic causes. Long-term medication and regular intake of sour foods are the most common extrinsic factors. The intrinsic factors include some diseases and/or their consequences (60). For example, in patients with gastro-esophageal reflux, the stomach acids reach oral cavity and cause a typical clinical picture of generalised dental erosions (60).

Prevention of Dental Decay Formation among Children with $\mathrm{CHD}$

The concept of early prevention lies on the thesis that primary teeth are usually sound when erupting and dental health during pre-school period is important, because it reflects the dental status of future mixed and permanent dentition, as well (16-19). The increased levels of oral health indices after 1970 are due to the early introduced informational meetings for parents, concerning oral health of their children, 
Prevalence of Dental Decay and Periodontal Diseases Among Children Suffering from Congenital Heart Diseases. ...

and also due to the higher extent of fluoride usage for the means of dental decay prophylaxis (29).

There are few mechanisms, through which fluorides imply their cariostatic effect. They include decrease of demineralisation, stimulation of remineralisation processes, influence over the formation and composition of dental pellicle and plaque, suppression of microbial growth and metabolism $(34,61-65)$. Small quantities of fluoride in saliva diminish the solubility of the mineral phase of hard dental tissues. Fluoride ions, incorporated into the mineral phase, cause the formation of a thin layer of fluorapatite crystals, and they are known for having higher levels of critical $\mathrm{pH}$ than hydroxyapatite. Fluoride may hinder bacterial metabolism by inhibiting the enolase enzyme and thus the synthesis of glucans by SM is disturbed (34, 66-69). All these mechanisms change the balance between de- and remineralisation in favour of remineralisation $(34,67,70)$.

The strong caries-protective effect of fluoride ions in acidified environment is due to the hydrofluoric acid formation and its rapid penetration through bacterial membranes $(71,72)$. Inside the cellular cytoplasm this acid may dissociate into fluoride and hydrogen ions again. The fluoride ion interferes with bacterial enolase and adenosintriphosphatase and thus hinders bacterial metabolism (70,71). The free hydrogen ion may cause acidification of the cytoplasm, which is fatal for the enzymes of the glycolytic process of fermentation $(71,73)$.

The effect of fluoride prophylaxis strongly correlates with the frequency of its application. Fluoride, included in everyday toothpastes, is believed to be the most effective form of individual exogenous fluoride prophylaxis at home (63), while the professional fluoride application of fluoride varnishes at the dental office on a six-month periods is the most efficient professional method for small children with a high risk for dental decay formation (74). For children with specific healthcare needs the regular daily endogenous intake of fluoride is of great importance. Both forms of endogenous fluoride prophylaxis - tablets and solutions, are told to prevent early childhood caries (ECC) among children with lip and/or cleft palates (75). In many countries, the main form of dental decay prophylaxis for healthy individuals consists of brushing with fluoride toothpaste twice a day. For some medically compromised patients, who are at higher risk for dental decay formation $(33,41,42,76)$, additional endogenous intake is indicated, after the precise dosage is adapted in accordance with personal needs and the level of compliance of the child and its parents (77).

\section{REFERENCES}

1. Peneva M, Tzolova E, Kabakchieva R, Rashkova M. Oral embryology, histology and biology. A Book of Pediatric Dentistry. Sofia; 2007.

2. Christensen LB, Twetman S, Sundby A. Oral health in children and adolescents with different socio-cultural and socio-economic backgrounds. Acta Odontol Scand. 2010;68(1):34-42. doi: 10.3109/00016350903301712.

3. Humphrey SP, Williamson RT. A review of saliva: normal composition, flow, and function. J Prosthet Dent. 2001;85(2):162-9. doi: 10.1067/ mpr.2001.113778.

4. Pollard MA, Curzon ME. Dental health and salivary Streptococcus mutans levels in a group of children with heart defects. Int J Paediatr Dent. 1992; 2(2):81-5.

5. Wong DT. Salivary Diagnostics. Singapore: WileyBlackwell; 2008.

6. da Silva DB, Souza IP, Cunha MC. Knowledge, attitudes and status of oral health in children at risk for infective endocarditis. Int J Paediatr Dent. 2002; 12(2):124-31.

7. Lagerlof F, Oliveby A. Caries-protective factors in saliva. Adv Dent Res. 1994;8(2):229- 38. doi: $10.1177 / 08959374940080021601$.

8. Dowd FJ. Saliva and dental caries. Dent Clin North Am. 1999;43(4):579-97.

9. Lenander-Lumikari M, Loimaranta V. Saliva and dental caries. Adv Dent Res. 2000;14:40-7. doi: 10.1177/08959374000140010601.

10. Tappuni AR, Challacombe SJ. A comparison of salivary immunoglobulin A (IgA) and IgA subclass concentrations in predentate and dentate children and adults. Oral Microbiol Immunol. 1994;9(3):142-5.

11. Slavkin HC, Baum BJ. Relationship of dental and oral pathology to systemic illness. JAMA. 2000;284(10):1215-7.

12. Organization WH (1992): Oral health surveys, basic methods, Geneva. 1997. California Strategic 
Teodora Nikolova, Radosveta Andreeva, Milena Georgieva et al.

Plan for Parental Involvement in Education. California Department of Education.

13. Fejerskov O, Kidd E, eds. Dental Caries. The disease and its clinical management. First ed. Copenhagen: Blackwell Munksggard; 2003.

14. Melo MA, Guedes SF, Xu HH, Rodrigues LK. Nanotechnology-based restorative materials for dental caries management. Trends Biotechnol. 2013;31(8): 459-67. doi: 10.1016/j.tibtech.2013.05.010.

15. Selwitz RH, Ismail AI, Pitts NB. Dental caries. Lancet. 2007;369(9555):51-9. doi: 10.1016/ S0140-6736(07)60031-2

16. Alm A, Wendt LK, Koch G, Birkhed D. Oral hygiene and parent-related factors during early childhood in relation to approximal caries at 15 years of age. Caries Res. 2008;42(1):28-36. doi: $10.1159 / 000111747$.

17. Alm A, Wendt LK, Koch G, Birkhed D. Prevalence of approximal caries in posterior teeth in 15-year-old Swedish teenagers in relation to their caries experience at 3 years of age. Caries Res. 2007;41(5):392-8. doi: 10.1159/000104798.

18. Grahn K, Wikstrom S, Nyman L, Rydberg A, Stecksen-Blicks C. Attitudes about dental care among parents whose children suffer from severe congenital heart disease: a case-control study. Int J Paediatr Dent. 2006;16(4):231-8. doi: 10.1111/j.1365-263X.2006.00736.x.

19. Skeie MS, Raadal M, Strand GV, Espelid I. The relationship between caries in the primary dentition at 5 years of age and permanent dentition at 10 years of age - a longitudinal study. Int J Paediatr Dent. 2006;16(3):152-60. doi: 10.1111/j.1365-263X.2006.00720.x.

20. Hara AT, Zero DT. The caries environment: saliva, pellicle, diet, and hard tissue ultrastructure. Dent Clin North Am. 2010;54(3):455-67. doi: 10.1016/j. cden.2010.03.008.

21. de Carvalho FG, Silva DS, Hebling J, Spolidorio LC, Spolidorio DM. Presence of mutans streptococci and Candida spp. in dental plaque/dentine of carious teeth and early childhood caries. Arch Oral Biol. 2006;51(11):1024-8. doi: 10.1016/j. archoralbio.2006.06.001.

22. Marsh PD. Microbiologic aspects of dental plaque and dental caries. Dent Clin North Am. 1999;43(4):599-614.

23. Bradshaw DJ, Marsh PD. Analysis of $\mathrm{pH}$-driven disruption of oral microbial communi- ties in vitro. Caries Res. 1998;32(6):456-62. doi: 10.1159/000016487.

24. Marsh PD. Dental plaque as a biofilm and a microbial community - implications for health and disease. BMC Oral Health. 2006;6 Suppl 1:S14. doi: 10.1186/1472-6831-6-S1-S14.

25. Marsh PD. Microbiology of dental plaque biofilms and their role in oral health and caries. Dent Clin North Am. 2010;54(3):441-54. doi: 10.1016/j. cden.2010.03.002.

26. Satish C, Shaleen C, Girish C, Kamala R. Oral medicine. Jaypee Brothers Medical Publishers; 2007.p. 153-8.

27. Fedak PWM, Verma S, David TE, Leask RL, Weisel RD, Butany J. Clinical and pathophysiological implications of a bicuspid aortic valve. Circulation. 2002;106(8):900-4.

28. Baltimore RS, Gewitz M, Baddour LM, Beerman LB, Jackson MA, Lockhart PB, et al. Infective endocarditis in childhood: 2015 update a scientific statement from the American heart association. Circulation. 2015;132(15):1487-515. doi: 10.1161/ CIR.0000000000000298.

29. Stecksen-Blicks C, Holm AK, Mayanagi H. Dental caries in Swedish 4-year-old children. Changes between 1967 and 1987. Swed Dent J. 1989;13(1-2):39-44.

30. Hoffman JI, Kaplan S. The incidence of congenital heart disease. J Am Coll Cardiol. 2002;39(12):1890-900.

31. Torres MC, Ramos ME, Coelho TL, Harari S. Salivary Streptococcus mutans and Lactobacillus sp levels in cardiac children. J Clin Pediatr Dent. 2001;26(1):103-9.

32. Stecksen-Blicks C, Kieri C, Nyman JE, Pilebro C, Borssen E. Caries prevalence and background factors in Swedish 4-year-old children - a 40-year perspective. Int J Paediatr Dent. 2008;18(5):317-24. doi: 10.1111/j.1365-263X.2008.00929.x.

33. Foster H, Fitzgerald J. Dental disease in children with chronic illness. Arch Dis Child. 2005;90(7):703-8. doi: 10.1136/adc.2004.058065.

34. American Academy of Pediatric Dentistry (AAPD). Guideline on periodicity of examination, preventive dental services, anticipatory guidance/counseling, and oral treatment for infants, children, and adolescents. Pediatr Dent. 2013; 35(5): E148-E156. 
Prevalence of Dental Decay and Periodontal Diseases Among Children Suffering from Congenital Heart Diseases. ...

35. Berger EN. Attitudes and preventive dental health behaviour in children with congenital cardiac disease. Aust Dent J. 1978;23(1):87-90.

36. Franco E, Saunders CP, Roberts GJ, Suwanprasit A. Dental disease, caries related microflora and salivary IgA of children with severe congenital cardiac disease: an epidemiological and oral microbial survey. Pediatr Dent 1996;18(3):228-35.

37. Hallett KB, Radford DJ, Seow WK. Oral health of children with congenital cardiac diseases: a controlled study. Pediatr Dent. 1992;14(4):224-30.

38. Pucéat M. Embryological origin of the endocardium and derived valve progenitor cells: from developmental biology to stem cell-based valve repair. Biochim Biophys Acta. 2013; 1833(4): 917-22. doi: 10.1016/j.bbamcr.2012.09.013.

39. Tasioula V, Balmer R, Parsons J. Dental health and treatment in a group of children with congenital heart disease. Pediatr Dent. 2008;30(4):323-8.

40. Valinoti AC, Da Silva Pierro VS, Da Silva EM, Maia LC. In vitro alterations in dental enamel exposed to acidic medicines. Int J Paediatr Dent. 2011;21(2):141-50. doi: 10.1111/j.1365-263X.2010.01104.x.

41. Engvall M, Sjogreen L, Kjellberg H, Robertson A, Sundell S, Kiliaridis S. Oral health in children and adolescents with myotonic dystrophy. Eur J Oral Sci. 2007;115(3):192-7. doi: 10.1111/j.1600-0722.2007.00446.x.

42. Stensson M, Wendt LK, Koch G, Oldaeus G, Birkhed D. Oral health in preschool children with asthma. Int J Paediatr Dent. 2008;18(4):243-50. doi: 10.1111/j.1365-263X.2008.00921.x.

43. Hayes PA, Fasules J. Dental screening of pediatric cardiac surgical patients. ASDC J Dent Child. 2001;68(4):255-8, 228-9.

44. Richardson $P$, McKenna W, Bristow M, Maisch B, Mautner B, O'Connell J, et al. Report of the 1995 World Health Organization/International Society and Federation of Cardiology Task Force on the definition and classification of cardiomyopathies. Circulation 1996;93(5):841-2.

45. Nunn JH, Ng SK, Sharkey I, Coulthard M. The dental implications of chronic use of acidic medicines in medically compromised children. Pharm World Sci. 2001;23(3):118- 9.

46. O'Sullivan EA, Curzon ME. Salivary factors affecting dental erosion in children. Caries Res. 2000;34(1): 82-7. doi: 10.1159/000016574.
47. Pomarico L, Czauski G, Portela MB, de Souza IP, Kneipp L, de Araujo Soares RM, et al. Cariogenic and erosive potential of the medication used by $\mathrm{HIV}$-infected children: $\mathrm{pH}$ and sugar concentration. Community Dent Health. 2008;25(3):170-2.

48. Nederfors T, Isaksson R, Mornstad H, Dahlof C. Prevalence of perceived symptoms of dry mouth in an adult Swedish population-relation to age, sex and pharmacotherapy. Community Dent Oral Epidemiol. 1997;25(3):211-6.

49. Sreebny LM, Schwartz SS. A reference guide to drugs and dry mouth. Gerodontology. 1986;5(2):75-99.

50. Scully C, Felix DH. Oral medicine -- update for the dental practitioner: dry mouth and disorders of salivation. Br Dent J. 2005;199(7):423-7. doi: 10.1038/ sj.bdj.4812740.

51. Streckfus CF. Salivary function and hypertension: a review of the literature and a case report. J Am Dent Assoc 1995;126:1012-7.

52. Nederfors T, Dahlof C, Twetman S. Effects of the beta-adrenoceptor antagonists atenolol and propranolol on human unstimulated whole saliva flow rate and protein composition. Scand J Dent Res. 1994;102(4):235-7.

53. Nederfors T, Dahlof C. Effects on salivary flow rate and composition of withdrawal of and re-exposure to the beta 1-selective antagonist metoprolol in a hypertensive patient population. Eur J Oral Sci. 1996;104(3):262-8.

54. Moore PA, Guggenheimer J. Medication-induced hyposalivation: etiology, diagnosis, and treatment. Compend Contin Educ Dent. 2008;29(1):50-5.

55. Nederfors T, Twetman S, Dahlof C. Effects of the thiazide diuretic bendroflumethiazide on salivary flow rate and composition. Scand J Dent Res. 1989;97(6):520-7.

56. Neves BG, Farah A, Lucas E, de Sousa VP, Maia LC. Are paediatric medicines risk factors for dental caries and dental erosion? Community Dent Health. 2010; 27(1):46-51.

57. van der Burgt I. Noonan syndrome. Orphanet J Rare Dis. 2007;2:4. doi: 10.1186/1750-1172-2-4.

58. Larsen MJ. Chemical events during tooth dissolution. J Dent Res. 1990;69 Spec No:575-80; discussion 634-6. doi: 10.1177/00220345900690S114.

59. Maupome G, Shulman JD, Medina-Solis CE, Ladeinde $\mathrm{O}$. Is there a relationship between asthma 
Teodora Nikolova, Radosveta Andreeva, Milena Georgieva et al.

and dental caries?: a critical review of the literature. J Am Dent Assoc. 2010;141(9):1061-74.

60. Johansson AK. Dental Erosion. Tandlakartidningen. 2004;97:57-61.

61. Assmusen E, Peutzfeldt A. Long-term fluoride release from a glass-ionomer cement, a compomer, and from experimental resin composites. Acta Odont Scand. 2002;60(2):93-7.

62. Mjor IA, Toffenetti F. Secondary caries: A literature review with case reports. Rest Dent. 2000; 31(3):165-79.

63. SBU. Att forebygga karies. En systematisk litteraturoversikt. SBU-rapport nr 161. Goteborg: Swedish Council on Technology Assessment in Health Care; 2002. (In Swedish)

64. Ten Cate JM. Fluorides in caries prevention and control: empiricism or science. Caries Res. 2004;38(3):254-7. DOI: 10.1159/000077763.

65. Twetman S. Prevention of early childhood caries (ECC)--review of literature published 1998-2007. Eur Arch Paediatr Dent. 2008;9(1):12-8.

66. Hooley M, Skouteris H, Boganin C. Parental influence and the development of dental caries in children aged 0-6 years: a systematic review of the literature. J Dent. 2012; 40(11): 873-85. doi: 10.1016/j. jdent.2012.07.013.

67. Vis JC, Duffels MG, Winter MM, Weijerman ME, Cobben JM, Huisman SA, et al. Down syndrome: a cardiovascular perspective. J Intellect Disabil Res. 2009;53(5):419-25. doi: 10.1111/j.1365-2788.2009.01158.x.

68. Yamamoto K1, Ohashi S, Aono M, Kokubo T, Yamada I, Yamauchi J. Antibacterial activity of silver ions implanted in $\mathrm{SiO} 2$ filler on oral streptococci. Dent Mater. 1996;12(4):227-9.

69. Zhang K, Melo MA, Cheng L, Weir MD, Bai Y, Xu $\mathrm{HH}$. Effect of quaternary ammonium and silver nanoparticle-containing adhesives on dentin bond strength and dental plaque microcosm biofilms. Dent. Mater. 2012;28(8):842-52. doi: 10.1016/j. dental.2012.04.027.

70. de Leeuw NH. Resisting the onset of hydroxyapatite dissolution through incorporation of fluoride. J Physl Chem B.2004;108(6):1809-11. doi: 10.1021/ jp036784v.

71. Kreulen CM, de Soet JJ, Weerheijm KL, van Amerongen WE. In vivo cariostatic effect of resin modified glass ionomer cement and amal- gam on dentine. Caries Res 1997; 31(5):384-9. doi: $10.1159 / 000262423$.

72. Nakajo K, Imazato S, Takahashi Y, Kiba W, Ebisu S, Takahashi N. Fluoride released from glass-ionomer cement is responsible to inhibit the acid production of caries-related oral streptococci. Dent Mater. 2009;25(6):703-8. doi: 10.1016/j.dental.2008.10.014.

73. Hüther FJ, Psarros N, Duschner H. Isolation, characterization, and inhibition kinetics of enolase from Streptococcus rattus FA-1. Infect Immun. 1990;58(4):1043-7.

74. Tylstrup A, Fejerskov O, eds. Textbook of Clinical Cariology. Copenhagen: Munksgaard; 1999.

75. Lin YT, Tsai CL. Comparative anti-caries effects of tablet and liquid fluorides in cleft children. J Clin Dent. 2000;11(4):104-6.

76. Bird DL, Robinson DS. Evolve resources for modern dental assisting. 11th edition, Elsevier-Saunders; 2015.p.258.

77. Koch G, Poulsen S, eds. Pediatric Dentistry A Clinical Approach. Second ed. West Sussex: WileyBlackwell; 2009. 